\title{
JEWS AND SOCIAL TRANSFORMATIONS IN POLESIE IN THE WORKS OF JÓZEF OBRĘBSKI
}

\begin{abstract}
The article studies the place of Jews in the work of Józef Obrębski about Polesie. They were an important part of his Polesie society triangle model. The model proved to be an effective instrument for the study of Polesie society but imposed noticeable restrictions on the author's understanding of the role of the Jews in Polesie. This functional analyses-based model helped Obrębski to show Jews as an extremely important mediatory element in the life of the Polesie society. But at the same time, it limited his understanding of the Jewish community mainly to this sole role. The article shows that the reason for this disbalance is not only the author's methods but also sources he used to get information about the Jewish life in the region.
\end{abstract}

Key words: Jews; Polesie; Józef Obrębski; ethnography; social functions

\section{JÓZEF OBRĘBSKI \\ ETNOSOCJOLOGIA \\ POLESIE WCZORAJ I DZIŚ}

\section{ŻYDZI A PRZEMIANY SPOLECZNE NA POLESIU W PRACACH JÓZEFA OBRĘBSKIEGO}

\section{Streszczenie}

Artykuł analizuje miejsce Żydów w poświęconych Polesiu pracach Józefa Obrębskiego. Stanowili oni istotny składnik w jego trójelementowym modelu społeczeństwa. Model ten sprawdzit się jako skuteczne narzędzie badawcze w odniesieniu do społeczności Polesia, zarazem jednak wyraźnie ograniczył autorskie rozumienie ról pełnionych przez Żydów w regionie. Dzięki temu funkcjonalnemu, wywiedzionemu z analiz modelowi Obrębski ukazał Żydów jako czynnik mediacyjny,
SIARHEI HRUNTOU Нацыянальная акадэмія навук Беларусі, Минск E-mail: szereszew@gmail.com http://orcid.org/0000-0001-5316-1180

CITATION: Hruntou, S. (2019) Jews and social transformations in Polesie in the works of Józef Obrębski. Sprawy Narodowościowe. Seria nowa, 2019(51). https://doi.org/10.11649/sn.1865

This work was supported by the author's own resources. No competing interests have been declared.

This is an Open Access article distributed under the terms of the Creative Commons Attribution 3.0 PL License (creativecommons.org/licenses/by/3.0/pl/), which permits redistribution, commercial and non-commercial, provided that the article is properly cited. (C) The Author(s) 2019

Publisher: Institute of Slavic Studies, Polish Academy of Sciences 
niezwykle istotny w życiu społecznym Polesia. Jednocześnie model ten zawęzit jego rozumienie społeczności żydowskiej głównie do tej właśnie roli. Artykuł pokazuje, że przyczyna tej dysproporcji leży nie tylko w metodzie autora, lecz także w charakterze źródet, z których czerpał on informacje o żydowskim życiu w regionie. [Przekł. Anna Engelking]

Słowa kluczow e: Żydzi; Polesie; Józef Obrębski; etnografia; funkcje społeczne

\footnotetext{
1
} he First World War and the years after brought not just a rapid change in the way of life of the people in Eastern Europe's rural regions, it also changed the way these regions and their population was studied by ethnologists and anthropologists. The scholars who studied East-Slavic ethnic groups and regions they inhabited were mesmerized with the idea of "archaic." They described "remnants of the ancient past" in the folklore, architecture, economics and in many other aspects of life (Богданович, 1895, p. 12; Романов, 1911, р. 1; Сербов, 1914, p. 35). In this way, they shaped the static model of the folk life and ignored or condemned the changes brought with modernization.

The new epoch that started after the First World War brought into the field a new generation of scholars who wanted to study the actual attitudes and conflicts in these local communities and to use newest methodological approaches in achieving these goals. Józef Obrębski was one of the brightest stars in this new generation. He was Bronisław Malinowski's doctoral student in the London School of Economics, conducted field research in Macedonia and in 1934 he came to Polesie to apply the newest ideas and approaches in the study of one of the most conservative and isolated regions in Eastern Europe.

Rapid modernisation of the region was not just a historical fact but also an important political issue. The Polish government was looking for ways to exert effective influence on this process that could help to integrate the region with its mixed population into the new Polish state. These circumstances helped Obrębski to get financial support for his expeditions for several years.

Józef Obrębski's studies of Polesie were focused on the local Slavic population known as "Poleshuks," that found itself between national identities of neighbouring ethnic groups of Poles, Belarusians and Ukranians in the interwar period (Терешкович, 2004, pp. 86-87, 181). This focus forms a research perspective that determines many other thematic blocks in his works. Some of these blocks grow into separate studies (e.g., the problem of school education), others occupy peripheral areas of this scholar's attention (sectarianism, local identities, etc.).

One of these thematic blocks is focused on the Jews of Polesie, an ethnic group that was an important part of local communities and quite often dominated in market towns of the region in its number and influence. Jews strongly influenced trade and economic contacts of local peasants with the outer world and became a part of their traditional worldview, that was determined by ethnic stereotypes and role models.

Starting his ambitious project on the study of Polesie and Poleshuks, Obrębski could not omit this important ethnic group and in one or the other way it is mentioned in all his major works on the region. One can find the most comprehensive survey of the topic in his work Archaic Polesie, never published in his lifetime. The main peculiarity of this work is that many parts of it are composed of extended quotes from works of other authors, followed with Obrębski's comments and conclusions. Chronologically, quotes cover the 
whole century, while the author uses them as factual blocks and usually makes no comments on their validity or content. With these quotes he builds and maintains his theoretical constructions and conclusions. As a result, this approach makes an ambiguous impression. The reader cannot clearly understand whether Obrębski shares the other authors' opinions or not, or when he distances himself from them with the use of quotation marks.

These peculiarities of Archaic Polesie are clearly visible when one tries to understand Obrębski's attitude toward the problem of the Jews of Polesie. That is why, first, it is necessary to understand the role of Jews in the theoretical frames that Obrębski uses to describe the Polesie society. Then, we can return to these quotes in order to understand what they mean within his theoretical structure.

Józef Obrębski, a disciple of the famous Bronisław Malinowski, uses a functionalist paradigm elaborated by his tutor, to describe the Polesie society as a complicated model where different historically formed groups interact (Engelking, 2004). Jews play an important role in this model. Together with the nobility and peasants they form a kind of a triangle where they act as a mediator between the first group and the other one, and also between each of these groups and the "outer world."

Such a function is necessarily based on the fact that, as Obrębski puts it, "nobility's system of economy was not economic but social in its core" (Obrębski, 2007, p. 80). According to this old system based on old feudal traditions of subordination, it was impossible to imagine commodity-money relations between the peasant and the nobleman. That would profane the very base of this relation. This position makes the role of the Jew indispensable and it grows even more significant after 1861 with all the economic and social changes after the Great Reforms. As the old model of society based on the feudal way of subordination was gradually declining, the new one, based on commoditymoney relations, starts to flourish. The role of the Jew grows in this model, as well as his power that increase dependence of peasants and nobility.

That is how Obrebski describes the circle of social roles of the Jews in Polesie: "Jewmerchant, Jew-shopkeeper, Jew-middleman, Jew-exporter and importer, Jew-profiteer, Jew-renter, Jew-informant-that is the image of all-around Jewish activity and the functions they have in noblemen's and peasant's economy" (Obrębski, 2007, p. 79). To this list one can add the Jew-tavern-keeper who is often mentioned on the pages of Archaic Polesie. But even with this addition, it is easy to note that social roles listed by the author often intersect, so that it would not be easy to separate the Jew-shopkeeper and Jew-profiteer. On the other hand, these functions underline the author's reduction of the social roles of Jews to a mediatory function in nobleman-peasant economic relations. Moreover, Obrębski believes that Jews cannot simply exist without it:

Being detached from the nobleman's fortune and nobleman's economy, the Jew falls to the very bottom of lumpen proletariat, that vegetates in poverty. The Jew-farmer who works on his own land, not on nobleman's as a peasant, the Jew who is free and serves to nobody, is unable to rise over the level of peasant in the time of serfdom (Obrębski, 2007, p. 80).

In this way, we get a paradoxically ambiguous picture. On the one hand, there is a brilliant analysis of the Polesie society and its dynamics in the 1930s, that shows social and economic functions of the Jewish population not only through economic connections but also through traditions and social conventions that were formed historically and were under deep transformations at the time of the author's expeditions to Polesie. On the other hand, one can see how the author falls into the trap of his own theoretic model and tends to reduce the existence of the whole ethnic group to one, though very extended, func- 
tion. Attention to social bounds and interactions leaves in shadow that part of community's life that do not aim at interacting with other ethnic groups. This includes all religious spheres with an extended system of cheders (religious schools) and courts of tzadiks (hasid movement leaders), as well as professions that concentrate on inside needs of the community within the shtetl, such as butchers or water carriers. Besides, the author ignores occupations that overlap and combine with some occupations of the Poleshuks. First of all, these include different crafts such as pottery, smithery, tannery-all well-developed among the Jews, and not worse than among the Polesie peasants.

Such skewness in Obrębski's understanding of the Jews of Polesie may be explained not only with conclusions following the interpretation model he has chosen, but also with a group of sources he uses in his text and his opinion about the role of Jews in Polesie. One can assume that his sources were much more numerous, but in his text Obrębski refers to few of them only. His main source is a travelogue of a prominent writer of the 19th century, "Memoirs of Wołyń, Polesie and Litwa," by Józef Ignacy Kraszewski (Kraszewski, 1840). Quotes from this book occupy whole pages. He takes similar quotes from the travel book by Pavel Shpilevski and adds some more quotes from the volume on the Minsk province of "Materials on Geography and Statistics of Russia, collected by the officers of the general base" and published in 1864 (Зеленский, 1864; Шпилевский, 1853). All these sources come from the mid-19th century and, being unquestionably useful and valuable, have one common feature. They describe the Jews from the point of view of an outside observer; that is why they highlight these parts of the Jewish life that were directed to the outer world, and thus were primarily visible. This observation explains such a strong attention to tavern-keepers, sellers and "factors" (agents-advisors). It cannot be free from the class point of view and can be attributed to the noblemen's point of view (though shared by clergymen and officials). At least, Kraszewski, whose quotes dominate here, was undoubtedly a prominent nobleman and this categorisation corresponds to the triangle model "noblemen-peasants—Jews" that Obrębski developed.

That is why the text includes many unfriendly characteristics of Jews as, for example, in this quote from Kraszewski:

The system of Jews used people's poverty, misery and mistakes. That was the base of the major part of their commercial and industrial deals. Landowner was deceived with hard cash, that he often lacked, peasant—with vodka, steward—with a mare and suppleness, etc. (Obrębski, 2007, p. 82).

A common object for strong criticism in these quotes is a tavern:

Let's pay attention and make certain in all these innumerable mischiefs that go from the fact that taverns are kept with Jews. Let's find a will to overview our situation and throw off this disgusting yoke. What a special agility, what spell do the Jews have, that under condition of so many inconveniences and obvious offences they are tolerated (Obrębski, 2007, p. 83).

This paper in no way aims to define the level of antisemitism in the views of Kraszewski and even how close these views were to Obrębski. We need to admit that Obrębski avoids assessments and studies situations from aside, as a model of a functioning system that gradually changes and declines. Moreover, the Jewish question in Polesie of the 1930s, or even of the 19th century, had completely different significance and meaning from the perspective of Warsaw in 1944, where Archaic Polesie was written.

Unfortunately, here we lose the points of view from the perspective of two other actors of this system-peasants and Jews themselves. They would help us to confirm the 
accuracy of the model of Polesie society, but also to make a shift in its axiological accents. Obrębski was not alone in the creation of such an exclusion. Jews are present only on the margins of "The Eastern Polesie" by Kazimierz Moszyński and "The Reczyca Polesie" by Czestaw Pietkiewicz, two well-known ethnographical works on Polesie published in the interwar period (Moszyński, 1928; Pietkiewicz, 1928, 1938). In the same way photos of Zofia Chomętowska ignore some exotic aspects of the Jewish life in Polesie (Chomętowska, 2011).

Just one example of an alternative perspective offers one quote from Volume I of "My Memories" by Yehezkel Kotick, a Jew from Kamenec town in the north-western corner of Polesie. Here he describes the situation of mass renting of noblemen's manors by Jews after the defeat of rebellion in 1863-64:

Grandfather first came up with a plan on how to help landowners, and at the same time to do something for the Jews. Namely: the Jews will take manors for rent from the ladies of a manor, that they are not able to manage; ladies will be literally saved, they will receive an annual reliable income and will not have to care about the ruined estates.

\section{And below:}

The landowners, who after some time returned home, exhausted and tormented by prisons and Siberia, did not recognize their possessions. Everything looked different: everywhere beauty, cleanliness and brilliance, many new buildings, machines and stables (Котик, 2009, pp. 225-226).

As was the case with Kraszewski, I will avoid commenting on the veracity of this information and the validity of such an interpretation of the facts. There is no doubt that tenancy, which is traditionally described as a vicious, "exploitative" practice, is shown here in a different, opposite perspective. Nevertheless, the relationships that are described here completely fit into the model built by Obrębski. In other words, it shows us the same model but with alternative meaning.

The figure of a Jew is, of course, also present in other works of Obrębski, as well as in the plans and sketches of works that he never wrote. For example, in the first volume of a large monograph about Polesie, the situation of the Jews was to be considered in the section "Public Environment Beyond the Borders of the Village." The content of the subsection on Jews is summarized by the author in one short paragraph:

\footnotetext{
A Jew is usually a tavern-keeper, a regular collector of goods for exchange and a supplier of market objects. Tavern: a meeting place for senior people, for fun, social gatherings. Permanent village club or people's house. Village attitude to a Jew devoid of all respect-on the contrary: the emphasis on the social superiority of the peasant. At the same time, great trust in the Jew in commercial affairs (Obrębski, 2007, p. 479).
}

This paragraph seems to summarize what Archaic Polesie said about the Jews, but it is still obvious that the function of the Jews here is again reduced to trade only.

However, it should be noted that this simplification is also related to the fact that the Jews in no way became a special research topic for Obrębski. He considers them indirectly through the social culture of the Polesie peasants, therefore the revealed onesidedness is formally sufficient for the author's research purposes. At the same time, his description of the relations of Polesie peasants and the Jews still has quite interesting remarks that are not reduced to the functional paradigm alone but rather show the peculiarities of the Poleshuk mentality. 
A vivid example is the preservation of the feeling of superiority of the peasant over the Jew, despite the economic domination of the latter. Such an attitude is well read on the implicit level, for example, in "Fairy Tales and Stories of the Belarusians-Poleshuks" by A.K. Serżputowski (1911), but the merit of Obrębski is that he articulates this paradox, brings it to the level of scientific fact, although he gives to it no further interpretation (Сержпутовский, 1911).

Describing relations with the Jews within the outlined model, Obrębski admits that they were not without conflicts, just as they were with the noblemen or priests. "This conflict, however, was relaxed and balanced by ties supported by relationships of dependence and reciprocity" (Obrębski, 2007, p. 508).

Describing the functioning of the Polesie society in the 1930, Obręski catches it in an era of great changes that radically transformed the way of life of the region. In this, he continues the tradition established by the first ethnographers who described Polesie in the mid-19th century and named it an archaic region that disappeared before their eyes. Predictably, Obrębski describes such a radical change as a dysfunction of the situations that marginalize and radicalize a significant part of the population, deprived of traditional ties that organized their lives. Naturally, the first victims of criminal intentions are other social and ethnic groups. Thus, enumerating examples of demoralization of Poleshuks, Obrębski writes:

Theft from a Jew (not neighbours): carrots, fruits, etc., left, abandoned values: linen, dried night; small items (ax), then larger-sleighs, etc. (Obrębski, 2007, p. 516).

However, the Jews themselves were actively marginalized-Obrębski recalls them, along with other social groups that contribute to the demoralization of village life:

Disorganisation as a result of instigation to crime (Jews, urban workers, professional criminals, shopkeepers, etc.)—-they learn to smoke, drink, steal and smuggle (Obrębski, 2007, p. 516).

In conclusion, I would like to draw attention to the forms of implicit Jewish presence in Józef Obrębski's texts about Polesie. For example, in the essay "A People without Fatherland", he gives the example of a joke that a resident of the village Vialikaja Gac' tells about the inhabitants of the village Bobrovichi:

One more word about them. They have such a feast called piacienka ("little Friday"), a large feast they have. They drink a lot on this day, they have a lot of vodka on this day. Thou, they are heavy drunk, they gather, ten or twenty of them...

Then we get a story about a group of idiots who just for a practical joke catch a dog, wind it round with a straw and fire it. The dog runs to the village and burnes it out. This text may be interpreted as a use of typical stereotypes about Jews (shabat and minyan, and may be even chasidic traditions in Poleshuk imagination) to mock the inhabitants of a neighbouring village. And the very example of stupidity of Bobrovichi villagers is very familiar to the folk stories about Jews' stupidity that Serżputowski collected in Polesie twenty years before.

Jews in Polesie texts of Józef Obrębski are shown as an integral part of the Polesie community, that is required for the normal life of all its participants. The researcher did not set goal of comprehensive description of this ethnic group, focusing mainly on the 
Slavic population of the region. Therefore, the image of the Jew, who appears on the pages of his works may seem one-sided and even biased. However, we need to remember that the Jews are never acting as an independent entity in his works, but rather as a mediatory function carrier in the social model, with the help of which the author analyses Polesie society. His triangle model (noblemen-peasants-Jews) is valuable itself and shows its potential even in analyses of the Belarusian peasants of later decades (Engelking, 2012). Without knowing the direction and results of the transformation, which is always realized only in retrospect, Obrębski describes the social transformation of the region as a dysfunction, as a disorder. Paradoxically, such a natural myopia gave a reliable picture from the perspective of the death of the major part of the Jewish community in the Holocaust and the inclusion of the region in a radically different social and economic order of the Soviet state.

Despite all these weak points in Obrębski's perspective on the Jews of Polesie, we may conclude that it still has some value for us today. The reason is that it helps to correct the view of the Jewish life in the region both in the works of Belarusian and Jewish authors. They both tend to focus on a static picture of Jewish everyday life mostly in the time before the First World War (Левитац, 2013). On the one hand (the Slavic), they give a perspective of the local peasants that was fixed in numerous folklore narrations (Белова, 2004, pp. 348-349). On the other, we have a Jewish perspective that focuses on statistics, economy, religious life or political movements (Zionists, Marxists, etc.) and their influence on the cultural life (Shohet, 2013, pp. 459-637; Вавренюк, 2011, 2013; Смиловицкий, 2008). In any way, the interwar period gets not so much attention because it is relatively short and overshadowed with subsequent tragical events.

Obrębski reminds us that the Jewish history in Polesie has its shady side with interior conflicts and marginalization processes. The author's own opinion on the role of the Jews in the life of Polesie remains opaque, but we may hope that further work with his archives will help to clarify this question.

\section{BIBLIOGRAPHY}

Chomętowska, J. (2011). Polesie: Fotografie z lat 1925-1939. Warszawa: Fundacja Archeologia Fotografii.

Engelking, A. (2004). Obrębski o Malinowskim. Z dziejów recepcji funkcjonalizmu w Polsce. Studia Socjologiczne, 2004(2(173)), 17-34.

Engelking, A. (2012). Kotchoźnicy: Antropologiczne studium tożsamości wsi białoruskiej przełomu XX i XXI wieku. Toruń: Wydawnictwo Naukowe Uniwersytetu Mikołaja Kopernika.

Kraszewski, J. (1840). Wspomnienia Wotynia, Polesia i Litwy (Vols. 1-2). Wilno.

Moszyński, K. (1928). Polesie Wschodnie; materjaty etnograficzne z wschodniej części b. powiatu mozyrskiego oraz z powiatu rzeczyckiego. Warszawa: Wydawn. Kasy im. Mianowskiego.

Obrębski, J. (2007). Studia etnosocjologiczne: Vol. 1. Polesie. Warszawa: Oficyna Naukowa.

Pietkiewicz, C. (1928). Polesie Rzeczyckie: Materjaty etnograficzne: Pt. 1. Kultura materjalna. Kraków: Polska Akad. Umiej. 
Pietkiewicz, C. (1938). Kultura duchowa Polesia Rzeczyckiego: Materjały etnograficzne. Warszawa: TNW.

Shohet, A. (2013). The Jews of Pinsk, 1881 to 1941. Stanford, MA: Stanford University Press. https://doi.org/10.11126/stanford/9780804741583.001.0001

Белова, О. (2004). "Народная Библия": Восточнославянские этиологические легенды. Москва: Индрик.

Богданович, А. (1895). Пережитки древнего миросозерцания у белоруссов. Гродна: Губернская типография.

Вавренюк, И. (2011). Демографические процессы еврейского населения Полесского воеводства. Тирош - труды по иудаике, 11, 135-148.

Вавренюк, И. (2013). Структура религиозного образования иудеев Западной Беларуси (1921-1939гг.). In Труды по еврейской истории и культуре: Материалы XX Международной ежегодной конференции по иудаике (Vol. 46/2, pp. 289-303). Москва: Институт славяноведения РАН.

Зеленский, И. (Ed.). (1864). Материалы для географии и статистики России, собранные офицерами Генерального штаба: Минская губерния (Pt. 1). Санкт-Петербург.

Котик, Е. (2009). Мои воспоминания. Санкт-Петербург: Издательство Европейского университета в Санкт-Петербурге.

Левитац, И. (2013). Еврейская община в России (1772-1917). Москва: Книжники.

Романов, Е. (1911). Материалы по этнографии Гродненской губернии (Vol. 1). Вильно: Издание Управления Виленского учебного округа.

Сербов, И. А. (1914). Поездки по Полесью 1911 и 1912 года. Вильна: Типография Иосифа Завадзкаго.

Сержпутовский, А. К. (1911). Сказки и рассказы белорусов-полешуков. Санкт-Петербург: Отд-ние рус. яз. и словесности Имп. АН.

Смиловицкий, Л. (2008). Евреи в Турове: История местечка Мозырского Полесья. Иерусалим: Tsur-Ot Press.

Терешкович, П. В. (2004). Этническая история Беларуси XIX - начала XX в. в контексте Центрально-Восточной Европы. Минск: БГУ.

Шпилевский, П. (1853). Путешествие по Полесью и Белорусскому краю. Санкт-Петербург.

\section{BIBLIOGRAPHY (TRANSLITERATION)}

Belova, O. (2004). "Narodnaia Bibliia": Vostochnoslavianskie ètiologicheskie legendy. Moskva: Indrik.

Bogdanovich, A. (1895). Perezhitki drevnego mirosozertsaniia u belorussov. Grodna: Gubernskaia tipografiia.

Chomętowska, J. (2011). Polesie: Fotografie z lat 1925-1939. Warszawa: Fundacja Archeologia Fotografii.

Engelking, A. (2004). Obrębski o Malinowskm. Z dziejów recepcji formalizmu w Polsce. Studia Socjologiczne, 2004(2(173)), 17-34.

Engelking, A. (2012). Kołchoźnicy: Antropologiczne studium tożsamości wsi białoruskiej przełomu XX i XXI wieku. Toruń: Wydawnictwo Naukowe Uniwersytetu Mikołaja Kopernika. 
Kotik, E. (2009). Moi vospominaniia. Sankt-Peterburg: Izdatel'stvo Evropeřskogo universiteta $\vee$ Sankt-Peterburge.

Kraszewski, J. (1840). Wspomnienia Wołynia, Polesia i Litwy (Vols. 1-2). Wilno.

Levitats, I. (2013). Evrěskaia obshchina v Rossii (1772-1917). Moskva: Knizhniki.

Moszyński, K. (1928). Polesie Wschodnie; materjaty etnograficzne z wschodniej czéści b. powiatu mozyrskiego oraz z powiatu rzeczyckiego. Warszawa: Wydawn. Kasy im. Mianowskiego.

Obrębski, J. (2007). Studia etnosocjologiczne: Vol. 1. Polesie. Warszawa: Oficyna Naukowa.

Pietkiewicz, C. (1928). Polesie Rzeczyckie: Materjaty etnograficzne: Pt. 1. Kultura materjalna. Kraków: Polska Akad. Umiej.

Pietkiewicz, C. (1938). Kultura duchowa Polesia Rzeczyckiego: Materjały etnograficzne. Warszawa: TNW.

Romanov, E. (1911). Materialy po étnografii Grodnenskol̆ gubernii (Vol. 1). Vil'no: Izdanie Upravleniia Vilenskogo uchebnogo okruga.

Serbov, I. A. (1914). Poezdki po Poles'iu 1911 i 1912 goda. Vil'na: Tipografiia losifa Zavadzkago.

Serzhputovskiĭ, A. K. (1911). Skazki i rasskazy belorusov-poleshukov. Sankt-Peterburg: Otd-nie rus. iaz. i slovesnosti Imp. AN.

Shohet, A. (2013). The Jews of Pinsk, 1881 to 1941. Stanford, MA: Stanford University Press. https://doi.org/10.11126/stanford/9780804741583.001.0001

Shpilevskiı̆, P. (1853). Puteshestvie po Poles'iu i Belorusskomu kraiu. Sankt-Peterburg.

Smilovitskiĭ, L. (2008). Evrei v Turove: Istoriia mestechka Mozyrskogo Poles'ia. Ierusalim: Tsur-Ot Press.

Tereshkovich, P. V. (2004). Étnicheskaia istoriia Belarusi XIX - nachala XX v. v kontekste TSentral' no-Vostochnoí Evropy. Minsk: BGU.

Vavreniuk, I. (2011). Demograficheskie protsessy evreľskogo naseleniia Polesskogo voevodstva. Tirosh-trudy po iudaike, 11, 135-148.

Vavreniuk, I. (2013). Struktura religioznogo obrazovaniia iudeev Zapadnoı̆ Belarusi (1921-1939 gg.). In Trudy po evreĭskor istorii i kul' ture: Materialy XX Mezhdunarodno ezhegodnoĭ konferentsii po iudaike (Vol. 46/2, pp. 289-303). Moskva: Institut slavianovedeniia RAN.

Zelenskiĭ, I. (Ed.). (1864). Materialy dlia geografii i statistiki Rossii, sobrannye ofitserami General' nogo shtaba: Minskaia guberniia (Pt. 1). Sankt-Peterburg. 